\title{
Biochemical alterations of red rice cultivated at soil water levels and organomineral fertilization
}

\author{
Katia Otilia Gomes Dutra', Toni Halan da Silva Irineu², Mário Leno Martins Véras³*, \\ Janailson Pereira de Figueredo4, Josimar Nogueora da Silva², \\ Raimundo Andrade', Carlos Henrique Salvino Gadelha Meneses'
}

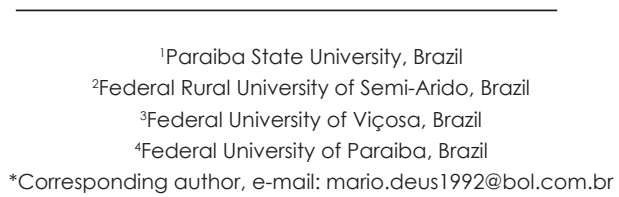

\begin{abstract}
Red rice is cultivated mainly by small farmers in the northeastern region of Brazil, a region characterized by water scarcity, that is why studies like those are needed aiming to save water without undermining crop cultivation. In this context, the objective was to evaluate in the red rice crop with application of silicon and biofertilizer: soil water levels, growth, productivity and biochemical parameters. The experiment was conducted in a protected environment at the State University of Paraíba, in the municipality of Catolé do Rocha-PB. The design was completely randomized, in the factorial arrangement $4 \times 2 \times 2$, with four replications. The treatments consisted of four levels of water in the soil $(70,80,90$ and $100 \%)$, with silicon and without silicon application, with biofertilizer and without biofertilizer application. Rice responded significantly to available water levels in the soil for all variables studied. Silicon and biofertilizer contributed to a better tolerance of rice to water stress. Organomineral fertilization increased the concentrations of the Proline, Glycine betaine and Trehalose osmoregulators. The lowest availability of water provided an increasement in the red rice osmoregulators concentration, that act as a plants protector against cell damages.
\end{abstract}

Keywords: Oryza sativa, water stress, silicon, organic fertilization.

\section{Introduction}

The rice culture presents significant relevance, since it is a food source for several Brazilian families. In the Northeast, rice is widely cultivated as a subsistence crop, however, studies highlights that crop requires water, light and nutrients (Menezes et al., 2011). In the Northeast region due to water scarcity is necessary a rational use of water resources, in the other hand, irrigation use is necessary for the rice cultivation, in addition also the management and distribution of water by irrigation methods are often inadequate.

Optimization of irrigation use, based on information improvement on soil water content, will avoid the waste of water resources observed in various situations. One of the most important factors in agricultural production is the irrigation, since water restriction is responsible for serious problems causing harmful changes in plants, due to the marked decrease in cellular turgor (Monteiro et al., 2014).

Several studies were carried out with the purpose of verifying the effect of water stress and its interaction with silicon in the rice culture, an example de Moro; Broetto; Moro (2015), Mauad; Crusciol; Grassi Filho (2011) e Mauad et al. (2013). However, in relation to the application of bovine biofertilizer in the rice crop there is no scientific information about its interaction with the water deficit and silicon application. 
Many rice producers use mineral fertilizers, silicon as an example, although this element does not belong to the essential elements group for plants, several studies have shown that silicon has a beneficial effect on rice (Mauad; Crusciol; Grassi Filho, 2011). However, due to the lack of studies related to its effects, there is no consensus on the relevance of the element. Some farmers use silicon fertilization in some crops, including in the rice crop, since it extracts the element in good quantity (Gutierrez; Inocêncio; Novelino $2011)$.

Nutritional supply is one of the most important cultural practices in the rice cultivation. The use of organic fertilizers, as a strategy of nourishment, increase the organic matter content in the soil promoting changes in their physical structure, among them, the bovine biofertilizer, which when applied via soil, it forms a protective layer in order to diminish high losses of evaporative water, allowing plant cells to remain turgid for longer (Silva et al., 2011).

In view of the above, the objective was to evaluate the following aspects: agronomic, growth, production and biochemical parameters in the red rice cultivation when cultivated under soil water levels, silicon and biofertilizer application.

\section{Material and methods}

The experiment was conducted in a greenhouse, from July 2012 to January 2013, at the Human and Agricultural Sciences Center$\mathrm{CCHA}$, belonging to the State University of Paraíba-UEPB, Campus IV, Catolé do Rocha-PB, located in the semi-arid region of northeastern Brazil, in the Northwest of the State of Paraíba.

The design was completely randomized, in the factorial arrangement $4 \times 2 \times 2$, with four replications. The treatments consisted of four levels of water in the soil (70, 80, 90 and 100\%), application of silicon (with and without) and biofertilizer (with and without). The experimental unit consisted of a synthetic polymer material vessel having volume $30 \mathrm{~L}$ with the substrate.

The water used in the irrigation presented electrical conductivity of $0.75 \mathrm{dS}$ $\mathrm{m}^{-1}$. The water analysis was performed by the Laboratory of Irrigation and Salinity (LIS) of the
Center of Technology and Natural Resources of the Federal University of Campina Grande - UFCG and presented the following chemical characteristics: $\mathrm{pH}=7,53 ; \mathrm{Ca}=2,30 \mathrm{cmol}_{\mathrm{c}} \mathrm{dm}^{-3} ; \mathrm{Mg}$ $=1,56 \mathrm{cmolc} \mathrm{dm}^{-3} ; \mathrm{Na}=4,00 \mathrm{cmol}_{\mathrm{c}} \mathrm{dm}^{-3} ; \mathrm{K}=0,02$ $\mathrm{cmol}_{\mathrm{c}} \mathrm{dm}^{-3}$; Cloreto $=3,90 \mathrm{cmol}_{\mathrm{C}} \mathrm{dm}^{-3}$; Carbonato $=0,57 \mathrm{cmol}_{\mathrm{c}} \mathrm{dm}^{-3}$; Bicarbonato $=3,85 \mathrm{cmol}_{\mathrm{c}} \mathrm{dm}^{-3}$; RAS $=2,88\left(\mathrm{mmol}_{\mathrm{C}} \mathrm{l}^{-1}\right)^{1 / 2}$.

The soil used for vessel filling was classified as Fluvic Neosol. Before the installation of the experiment, simple soil samples were collected in the field, from the 0 to $30 \mathrm{~cm}$ layer, being homogenized and transformed into composite samples, where they were sent and analyzed in the laboratory to determine the physicalchemical attributes. The soil was analyzed and has shown the following characteristics: $\mathrm{pH}=$ 6,00; $\mathrm{Ca}=2,34 \mathrm{cmol}_{\mathrm{c}} \mathrm{dm}^{-3} ; \mathrm{Mg}^{2}=2,41 \mathrm{cmol}_{\mathrm{c}} \mathrm{dm}^{-3}$; $\mathrm{Na}=0,02 \mathrm{cmol}_{\mathrm{c}} \mathrm{dm}^{-3} ; \mathrm{K}=0,33 \mathrm{cmol}_{\mathrm{c}} \mathrm{dm}^{-3}$; Sum of bases $-\mathrm{SB}=5,10 \mathrm{cmol}_{\mathrm{c}} \mathrm{dm}^{-3} ; \mathrm{H}+\mathrm{Al}=0,69 \mathrm{cmol}_{\mathrm{c}}$ $\mathrm{dm}^{-3} ; \mathrm{CTC}=5,79 ; \vee(\%)=88$ e Organic matter $=$ $0,81 \mathrm{~g} \mathrm{~kg}^{-1}$.

The substrate used was composed of soil and earthworm humus in a ratio of $1: 1$. The worm humus analysis was performed and presented the following characteristics (Table 1). The preparation of the substrate for the red rice cultivation was carried out manually using the Fluvic Neosol soil and California red worms humus in a ratio of $1: 1$, allowing the substrate to receive the red rice seeds packed in vessels with a capacity of $30 \mathrm{~kg}$.

The seeds used in the sowing were certified and were treated in water for 24 hours to guarantee the emergence of more vigorous seedlings. The sowing was done directly in the vessel, the thinning was done in order to leave the plant more vigorous at 15 days after sowing.

The biofertilizer was obtained by anaerobic fermentation, that is, in a hermetically sealed environment. For the preparation of the biofertilizer, one end of a thin hose was coupled and the other end was immersed in a vessel with water to release the methane gas at the top of each biodigester, $70 \mathrm{~kg}$ of bovine manure from lactating cows and 120 liters of water were used, adding $5 \mathrm{~kg}$ of sugar and 5 liters of milk to accelerate bacteria metabolism.

For application of silicon into red 
rice plants was used SIFOL with $12 \% \mathrm{Si}$, with dosages of $50 \mathrm{~g}$ of $\mathrm{Si} / 100$, according to the product label use instructions. It was starting at 15 days after tillering until the hardening of the panicle.

The application was done manually using a disposable syringe through the soil.
Prior to application, the biofertilizer was subjected to the screen filtration process in order to reduce the risks of sprinkler holes obstruction. The biofertilizer was analyzed and presented the following physicochemical characteristics (Table 1):

Table 1. Physical-chemical attributes of the earthworm humus and bovine biofertilizer used in the experiment. Catolé do Rocha - PB, UEPB.

\begin{tabular}{|c|c|c|c|}
\hline Earthworm humus & Values & Bovine Biofertilizer & Values \\
\hline $\mathrm{pH} \mathrm{H} \mathrm{H}_{2} \mathrm{O}(1: 2,5)$ & 7,38 & $\mathrm{pH} \mathrm{H}_{2} \mathrm{O}(1: 2,5)$ & 4,68 \\
\hline Electric conductivity ( $\mathrm{dS} \mathrm{m}^{-1}$ ) & 2,11 & Electric conductivity $\left(\mathrm{dS} \mathrm{m}^{-1}\right.$ ) & 4,70 \\
\hline Calcium $\left(\mathrm{cmol}_{\mathrm{c}} \mathrm{dm}^{-3}\right)$ & 3,54 & Calcium $\left(\mathrm{cmol}_{\mathrm{c}} \mathrm{dm}^{-3}\right)$ & 3,75 \\
\hline Magnesium $\left(\mathrm{cmol}_{\mathrm{c}} \mathrm{dm}^{-3}\right)$ & 1,93 & Magnesium $\left(\mathrm{cmol}_{\mathrm{c}} \mathrm{dm}^{-3}\right)$ & 3,30 \\
\hline Sodium $\left(\mathrm{cmol}_{\mathrm{c}} \mathrm{dm}^{-3}\right)$ & 0,18 & Sodium $\left(\mathrm{cmol}_{\mathrm{c}} \mathrm{dm}^{-3}\right)$ & 1,14 \\
\hline Potassium $\left(\mathrm{cmol}_{\mathrm{c}} \mathrm{dm}^{-3}\right)$ & 0,14 & Potassium $\left(\mathrm{cmol}_{\mathrm{c}} \mathrm{dm}^{-3}\right)$ & 0,71 \\
\hline$S\left(\mathrm{cmol}_{\mathrm{C}} \mathrm{dm}^{-3}\right)$ & 5,79 & $S\left(\mathrm{cmol}_{\mathrm{c}} \mathrm{dm}^{-3}\right)$ & 14,45 \\
\hline Hydrogen $\left(\mathrm{cmol}_{\mathrm{c}} \mathrm{dm}^{-3}\right)$ & 0,00 & Hydrogen $\left(\mathrm{cmol}_{\mathrm{c}} \mathrm{dm}^{-3}\right)$ & 1,00 \\
\hline Aluminum $\left(\mathrm{cmol}_{\mathrm{c}} \mathrm{dm}^{-3}\right)$ & 0,00 & Aluminum $\left(\mathrm{cmol}_{\mathrm{c}} \mathrm{dm}^{-3}\right)$ & 0,00 \\
\hline Assimilable Phosphorus $\left(\mathrm{cmol}_{\mathrm{c}} \mathrm{dm}^{-3}\right)$ & 5,51 & Assimilable Phosphorus $\left(\mathrm{cmol}_{\mathrm{c}} \mathrm{dm}^{-3}\right)$ & 14,45 \\
\hline
\end{tabular}

The soil water content was monitored daily by the indirect method using a humidity meter (model HH2 Moisture Meter brand Delta-T Devices Ltd.) with capacitance multi-sensor probe inserted in the soil through a polycarbonate tube (Reflectometry in the Frequency Domain - RFD), with approximately $2.5 \mathrm{~cm}$ of external diameter and little more than one meter long, properly configured to measure soil moisture at depths of $10,20,30,40,60$ and $100 \mathrm{~cm}$, exactly where the electronic sensors are installed in the probe, visualized in the form of pairs of stainless steel rings. An adaptation was made in the vessel because the equipment has a larger size than the vessel used in the experiment, thus regulating the tube to be able to measure only the determined layers comprising 10 to $40 \mathrm{~cm}$.

The data was read using portable equipment, with an electronic viewfinder, called $\mathrm{HH}$ 2, where it records the results of the humidity readings in percentage (\%).Values were inserted and processed on a Microsoft ${ }^{\circledR}$ Exce $^{\circledR}$ worksheet. The balance of the total water content in the soil was calculated according to equation 1, where the volume of water to be applied in each vessel was only to maintain the humidity corresponding to the levels of $70,80,90$ and $100 \%$ of available water (Albuquerque, 2010).

$$
A W=(C c-P M P)-(C a-P M P) \times V / 100(\text { eq. 1) }
$$

Where: AW - Volume of Available water; CC - Humidity at field capacity; PMP - Humidity corresponding to the permanent wilting point; Ca - Humidity to current soil capacity; $V$ - Soil volume $\left(\mathrm{cm}^{-3}\right)$.

Daily the quantities of water consumed by the plants were processed in volume obtained from the readings made through the FDR. The water requirement of the crop was supplied manually, with water supplied through a watering can, according to FDR (Reflectometry in Frequency Domain) monitoring.

Harvesting was done manually at 180 days after sowing (DAS), performing the cutting, entangling and harvesting operations when the grains of red rice were between 18 to $23 \%$ humidity.

The evaluations regarding the growth and production components of the red rice crop were analyzed according to the results obtained by plant height, number of panicles per clump, number of spikelets per panicle, number of grains per spikelets and number of grains per clump. Also were analyzed: Trehalose, by the method described by Neves et al. (1994), Proline content, determined using the Bates method; Waldren; Teare (1973) and Glycine-cetatin, determined according to the method of Grieve and Grattan (1983). 
The data were submitted to analysis of variance, comparing the average obtained with the qualitative factor (silicon and biofertilizer) by the Tukey test and performing regression analysis for the quantitative factor (irrigation slides). Statistical software SISVAR 5.1 was used to perform analysis and regression models (Ferreira, 2007).

\section{Results and discussion}

About red rice crop the statistical analysis of the growth and production variables revealed a significant effect of available water levels (AD) on the soil for all variables analyzed. The application of silicon had a significant effect only on spikelets and grains per spikelet numbers. The biofertilizer was significant only for grains per spikelet and grains per clump numbers. On the other hand, the interactions among the study factors did not show a significant difference in the red rice characteristics (Table 2).

Table2. Analysis summary of variance and production growth on red rice culture related to factors involved in the experiment in a protected environment. ** and * significance at the 0.01 and 0.05 probability levels by the Tukey test, respectively. $\mathrm{PH}=$ plant height, NPC = number of panicles per clump, NS = number of spikelets, NGS = number of grains per spikelet, NGC = number of grains per clump.

\begin{tabular}{|c|c|c|c|c|c|c|}
\hline Source of variation & FD & & Medium & Square & & \\
\hline & & $\mathrm{PH}$ & NPC & NS & NGS & NGC \\
\hline Water levels (L) & 3 & $1169,20^{* *}$ & $5614,68^{* *}$ & $332,39 * *$ & $332,39 * *$ & $174456296,30^{* *}$ \\
\hline Silício (Si) & 1 & $18,06^{\mathrm{ns}}$ & $105,06^{\mathrm{ns}}$ & $313,89 * *$ & $206,64^{* *}$ & $739385,01^{\mathrm{ns}}$ \\
\hline Biofertilizer (B) & 1 & $206,64 \mathrm{~ns}$ & 855,56 ns & $118,26 \mathrm{~ns}$ & $118,26^{*}$ & $51135013,26^{* *}$ \\
\hline Inter. (L x Si) & 3 & $298,35 \mathrm{~ns}$ & 310,43 ns & 89,34 ns & $89,76^{\mathrm{ns}}$ & $24144235,18^{\text {ns }}$ \\
\hline Inter. $(L \times B)$ & 3 & $156,05^{\mathrm{ns}}$ & $141,43^{\mathrm{ns}}$ & 96,30 ns & 96,30 ns & $17460808,18^{\text {ns }}$ \\
\hline Inter. (Si x B) & 1 & $328,51 \mathrm{~ns}$ & 217,56 ns & 1,26 ns & $0,76^{\mathrm{ns}}$ & $4079895,01 \mathrm{~ns}$ \\
\hline Inter. ( $\mathrm{L} \times \mathrm{Si} \times \mathrm{B})$ & 3 & 79,01 ns & $82,52 \mathrm{~ns}$ & $74,30 \mathrm{~ns}$ & 75,30 ns & 1847789,34 ns \\
\hline Residue & 48 & 71,78 & 127,17 & 25,59 & 25,58 & 5101947,47 \\
\hline VC (\%) & & 30,19 & 31,91 & 30,87 & 30,86 & 41,30 \\
\hline
\end{tabular}

When was analyzing the height of red rice plants, was noticed a growing linear behavior with increasing water availability in the soil (AD). As AD levels increased, there was an increase in height of $0.62 \mathrm{~cm}$ per unit increase of $A D$, and the maximum level allowed an increase of $98 \%$ in relation to the values found in the lowest blade (Figure 1A). One of the effects of water deficiency on rice crop is the plant height reduction caused by the lower cellular turgor since the rate of assimilation of $\mathrm{CO}_{2}$ is reduced (Guimarães et al., 2011).
A growing linear tendency in the number of panicles per clump with increase of $A D$ level was noticed (Figure 1B), showing a growth of 1.44 panicles per clump, per unit increase of $A D$, obtaining at the maximum level (100\%) 39 panicles per clump, exceeding by $270 \%$ the value obtained minimum level (70\%).

Probably, this increase in the number of panicles per clump is due to the potential benefits of irrigation with a deficit that comes from factors such as irrigation efficiency improvement. It can be verified that the high number of panicles

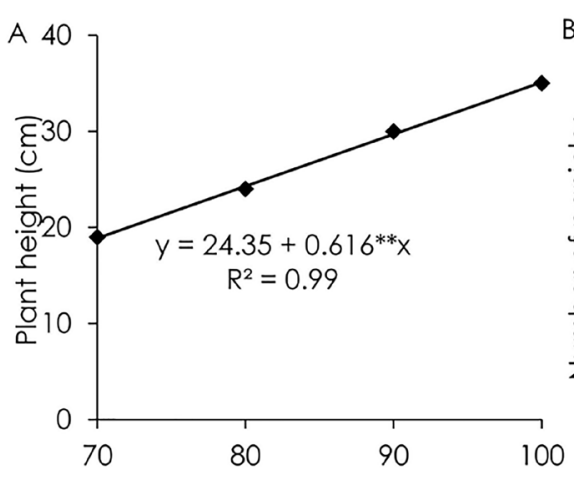

Water levels avaliable (\%)

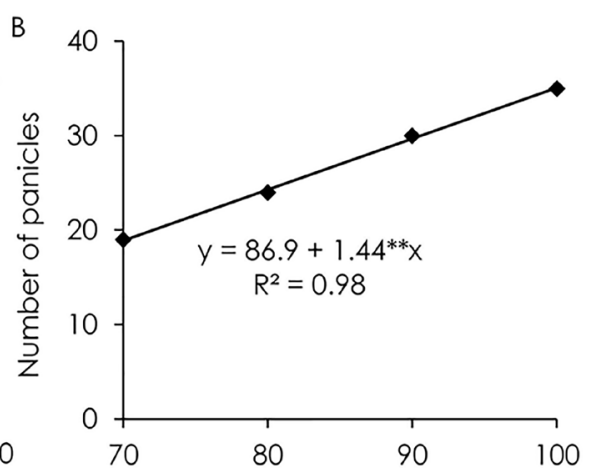

Water levels avaliable (\%)

Figure 1: Effect of available water levels at plant height (A) and the number of panicles of red rice (B). ${ }^{* *}, *$, significant at 1 and $5 \%$ and not significant respectively. 
per clump occurred, possibly due to the high tillering capacity and the production of spikelets, respectively, confirmed by the values of the panicle production component observed in this experiment.

The number of spikelets was influenced by the $A D$ levels, and the maximum values were found in the lowest water availability (70\%) with 21 spikelets and the lowest value (11 spikelets) in the highest $A D$ level (100\%), reduction of $47.6 \%$ when the level of $A D$ increased and decrease of 0.33 spikelets per unit increase of AD level(Figure 2A).

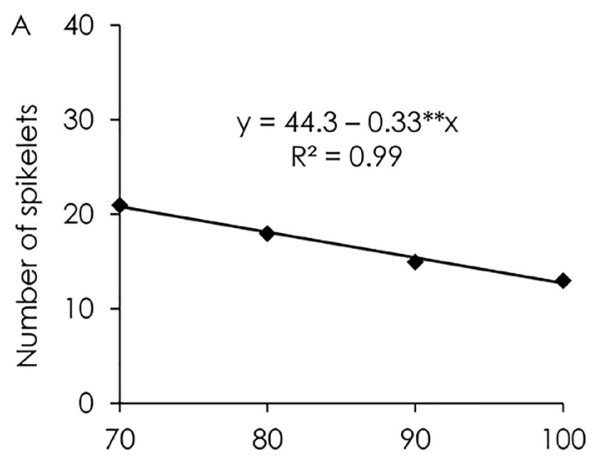

Water levels avaliable (\%)

Figure 2: Effect of available water levels (A) and application of silicon (B) on the number of red rice spikelets. ${ }^{* *}, *$, significant at 1 and $5 \%$ and not significant respectively

Rice culture is one of the grasses that most absorb silicon, since the element is translocated, accompanying the plant respiration process then it is accumulated in the aerial part of the rice (Oliveira; Korndörfer; Pereira, 2007).

The number of grains per spikelet was reduced linearly with the increase of $A D$ levels, with a reduction of 0.36 grains per unit increase of the applied $A D$, corresponding in the highest $A D$ level (100\%) in the number of grains (Figure $3 \mathrm{~A})$. With regard to apply silicon, there was a significant increase in the number of grains per
The Utilization of silicon affected the number of spikelets per plant, with a significant enhancement of $28 \%$, corresponding to the increase of four spikelets per panicle (Figure $2 \mathrm{~B})$. The silicon reduces the rate of transpiration, influencing the reduction of water loss in the transpiration process, also may increase in the gain of production. In addition, the element acts in the plant defense against pests and diseases, and as a consequence, it makes the plant more resistant, thus reducing the use of chemical pesticides.

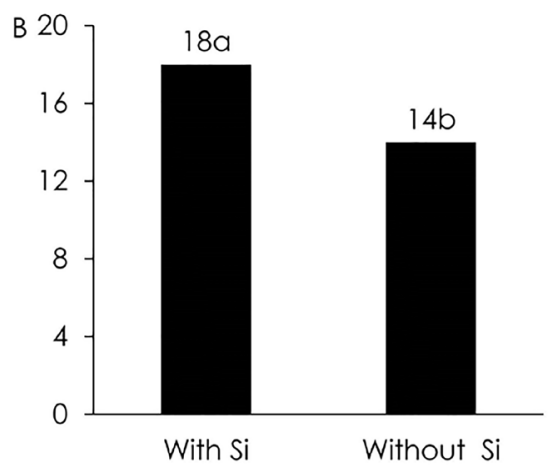

spikelet when this element was applied. Notice that between plants with silicon and the control plants, plants with the use of the chemical element were the ones with the highest number of grains, corresponding to the increase of $20 \%$ in compared to the treatments that did not receive the silicon application (Figure 3B).

This increase caused by the application of silicon is due to its positive effect. The element is accumulated in the stomata, small openings or pores located in the epidermis of most aerial organs of plants. Thus, possibly, it would
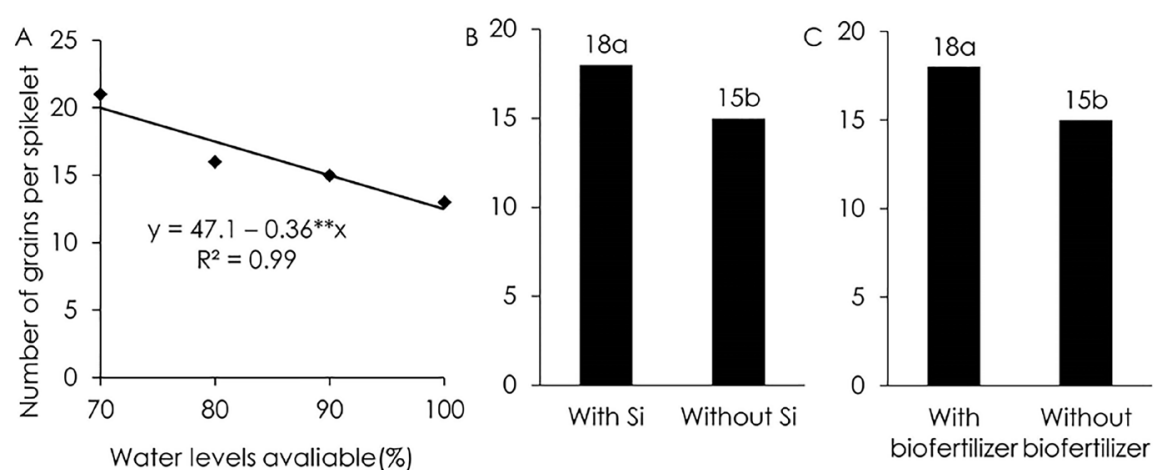

Figure 3: Effect of available water levels (A) application of silicon (B) and biofertilizer (C) on the number of grains per spikelet of red rice. ${ }^{* *}, *$, significant at 1 and $5 \%$ and not significant respectively 
have provided a formation of a double layer of cuticular silica, and as a consequence, it reduced the transpiration rate of the plants, causing a decrease in water requirements besides increasing the efficiency in the use of water by the plant and the photosynthetic rate as well (Nwugo; Huerta, 2008).

In both cases, with and without biofertilizer application in the rice plants, it was observed that the best results were obtained with the application of biofertilizer, corresponding to a value of 18 grains per spikelet (Figure $3 \mathrm{C}$ ). Possibly, the biofertilizer provided this superiority due to the greater availability of nutrients.

It is important to emphasize that the application of bovine biofertilizer makes possible an increase in the production, due to the supply of organic matter that improves soil physical aspects and several beneficial substances, such as $\mathrm{N}, \mathrm{P}$ and $\mathrm{K}$, thus providing nourishment to the plants (Diniz et al., 2011).

The regression equation adjusted to the experimental data on the number of grains per clump in relation to $A D$ levels was significantly affected (Table 1). It was observed that the number of grains per clump increased linearly with the increase of water availability in the soil, evidencing an increase of 252.14 grains in each unit increase of $A D$ levels, where at the maximum level (100\% AD) was found 9250 grains (70\% AD) 1686 grains, with a difference of $448 \%$ among the observed values (Figure 4A).
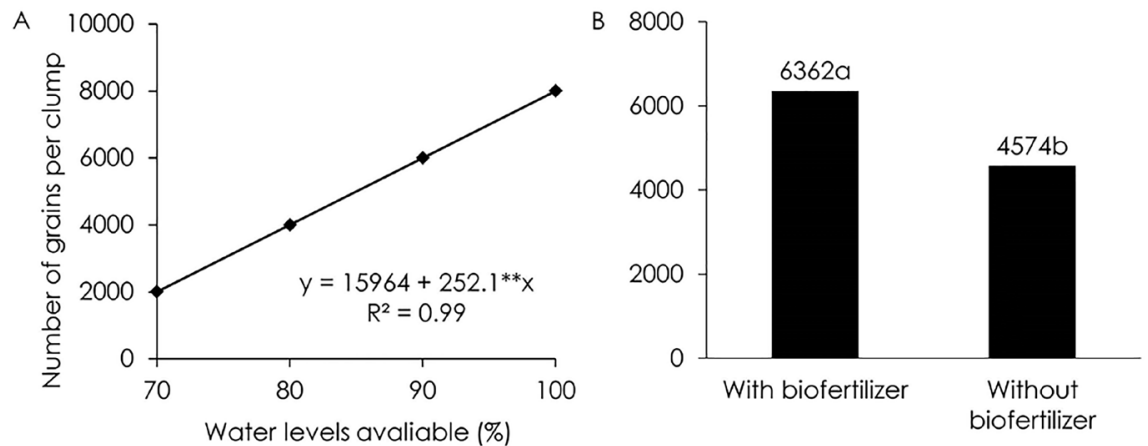

Figure 4: Effect of available water levels (A) and application of biofertilizer (B) on the number of grains per clump of red rice. ${ }^{* *}, *$, significant at 1 and $5 \%$ and not significant respectively

With Regard to the use of the biofertilizer, there was an increase of $39.09 \%$ in the number of grains per clump with its application, resulting in a significant effect (Figure 4B). Notice that the sustainable management of organic fertilizer applied in the red rice plants can be related to the phosphorus and nitrogen content in the product (Table 3).
One of the advantages of the use of the biofertilizer is the ease of acquisition since they are produced with materials composed of animal excrement, these products could be produced by the farmer and consequently reducing the expenses with synthetic fertilizers and reducing the environmental impacts (Medeiros et al., 2007).

Table 3: Summary of the variance analysis of the biochemical analyzes of the red rice culture of the factors involved in the experiment in a protected environment. ${ }^{* *}$ and * meanings at the 0.01 and 0.05 probability levels by Tukey's test, respectively.

\begin{tabular}{|c|c|c|c|c|}
\hline \multirow[t]{2}{*}{ Source of variation } & \multirow[t]{2}{*}{$\mathrm{FD}$} & \multicolumn{3}{|c|}{ Medium Square } \\
\hline & & Proline & Glicine & Trehalose \\
\hline Water levels (L) & 3 & $0,296^{* *}$ & $125,216^{* *}$ & $0,130^{* *}$ \\
\hline Silício (Si) & 1 & $0,348^{* *}$ & $3217,867^{* *}$ & $0,960^{* *}$ \\
\hline Biofertilizer (B) & 1 & $1,000 * *$ & $130,902^{* *}$ & $0,286^{* *}$ \\
\hline Inter. (L x Si) & 3 & 0,254 ns & $602,924 \mathrm{~ns}$ & $0,125^{\mathrm{ns}}$ \\
\hline Inter. $(L \times B)$ & 3 & $0,002^{\text {ns }}$ & 151,755 ns & $0,051^{\mathrm{ns}}$ \\
\hline Inter. $(\mathrm{Si} \times \mathrm{B})$ & 1 & 0,409 ns & 824,766 ns & $0,372^{\text {ns }}$ \\
\hline Inter. ( $L \times \operatorname{Si} \times B)$ & 3 & $0,011^{\text {ns }}$ & $335,015^{\text {ns }}$ & $0,026^{\text {ns }}$ \\
\hline Residue & 48 & 0,002 & 0,687 & 0,004 \\
\hline VC (\%) & & 10,58 & 1,38 & 4,39 \\
\hline
\end{tabular}


The statistical analysis of the red rice biochemical variables (Table 3), at 180 days after sowing (DAS), revealed the statistical significance of soil water available level (AD), silicon and biofertilizer about Proline, Glycinebeta and Trehalose concentration. For all the studied variables, the interactions did not present statistical significance, indicating that the water levels behaved in a similar way within the silicon and biofertilizer application form and vice versa.

It can be observed in Figure 5A, when the lowest AD level (70\%) was applied, there was intensification of Proline level, that is, when the rice underwent a major water deficit, thus presenting a significant effect on red rice in $(A D)$, resulting in the accumulation of Proline, which evidences its osmoprotective function, thus maintaining the water balance of the rice and preserving the cellular integrity of proteins, enzymes and membranes, constituting one of the adaptive strategies of vegetables to the multiple effects caused by stresses, according to Abdul and Jaleel et al. (2007). It is also noticed that there was a decrease in proline concentration as the level of water in the soil increased.
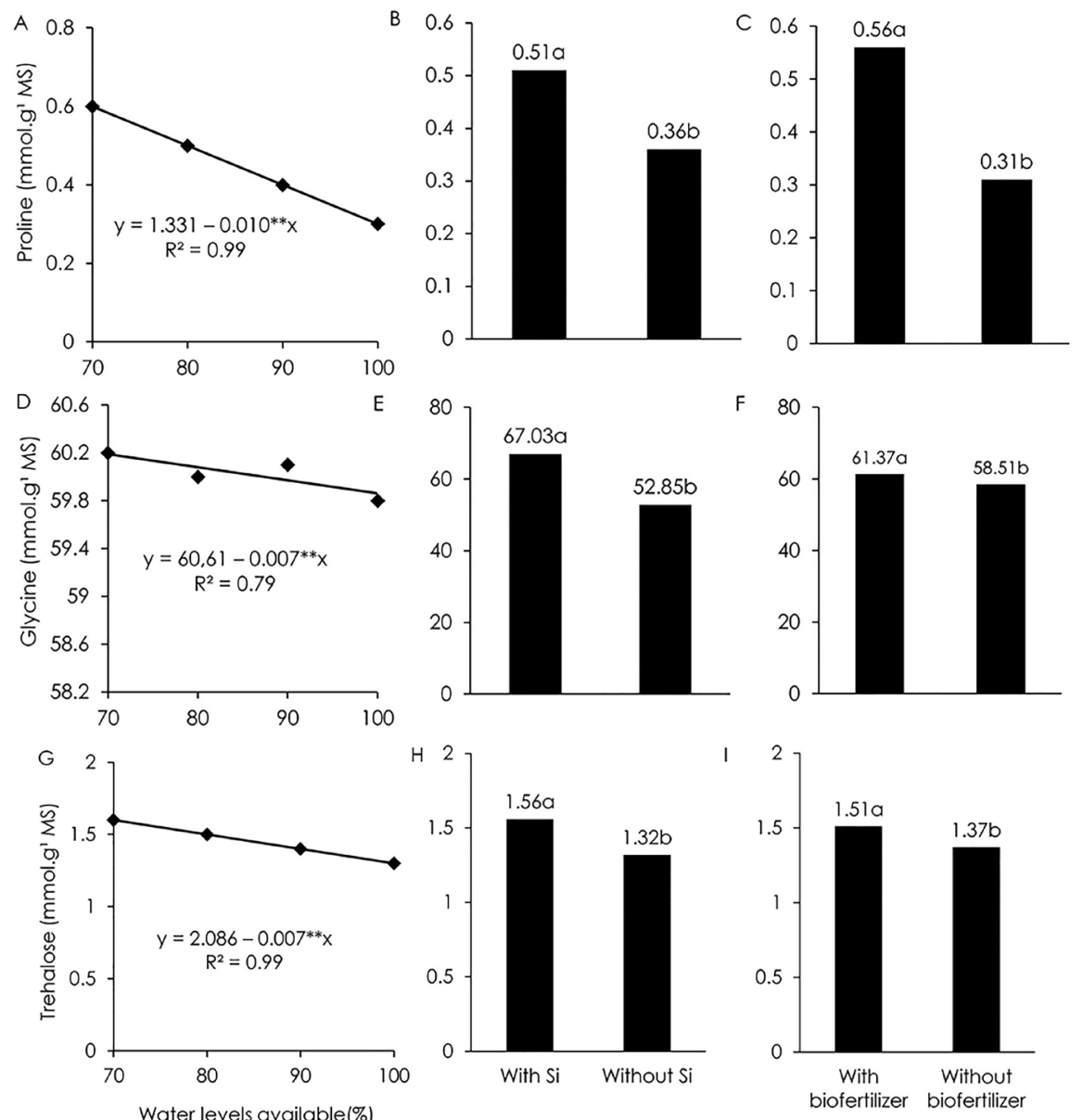

Figure 5: Effect of available water levels, application of silicon and biofertilizer on the content of Proline (A, $B$ and $C)$, Glycine (D, E and F) and Trehalose (G, H and I) of red rice. ${ }^{* *}$, ${ }^{*}$, significant at 1 and $5 \%$ and not significant respectively

Under stress plants can increase Proline content as compared to plants grown under normal conditions, and this increase in Proline content is important for the selection of resistant plants (Verbruggen e Hermans, 2008). Another point is that the levels of Proline are higher in plants that are under water stress (Cvikrová et al., 2013; Filippou et al., 2014).
The treatments that received the application of silicon and biofertilizer also increased free proline levels in red rice (Figure $5 B$ and $C$ ), resulting in a significant effect at 0.01 . When plants are subjected to stresses, such as water stress, the silicon application increases the plant resistance (Pulz et al., 2008).

The use of bovine biofertilizer presents 
several benefits, among them the increment in the development of the plants, however, each culture responds differently depending on its necessity (Chiconato et al., 2013).

Related to Glycine betaine action in red rice, an accumulation of $0.43 \%$ of this osmoprotectant was observed as a function of AD levels, a decrease of this amino acid occurs from the increase of these levels (Figure 5D), that is a greater incidence of this amino acid with an increase of the water restriction.

In the treatments in which silicon and biofertilizer were applied, there was also an increase in Glycine betaine levels, resulting in a significant effect on both factors (Figure $5 \mathrm{E}$ and $\mathrm{F}$ ). Glycine betaine protects thylakoid membranes, and then it maintains photochemical efficiency in photosynthesis (Ashraf e Foolad, 2007).

As a function of soil water levels, rice showed capacity for Trehalose accumulation (Figure 5G), a decrease of this amino acid occurs as AD levels increased, was possible to observe a greater accumulation of the osmolyte in the lower level of AD (70\%), obtaining a significant effect for the studied factor in the red rice crop. With regard to the treatments which silicon (Figure $5 \mathrm{H}$ ) and biofertilizer (Figure 5I) were applied, the amino acid referred above has shown a significant effect on red rice.

\section{Conclusion}

The lower availability of water in the cultivation of red rice increased the concentration of osmoregulators, thus activating the protection against cellular damages;

Silicon and biofertilizer use provided higher growth and yield in the red rice;

Organomineral fertilization (Silicon and Biofertilizer) increased the concentrations of the Proline osmolytes, Glycine betaine and Trehalose.

\section{Referências}

Abdul Jaleel, C., Manivannan, P., Kishorekumar, A., Sankar, B., Gopi, R., Somasundaram, R., Panneerselvam, R. 2007. Alterations in osmoregulations, antioxidant enzymes and indole alkaloid levels in Catharanthus roseus exposed to water deficit. Colloids and Surfaces B: Biointerfaces 59: 150-157.

Albuquerque, P. E. P. 2010. Estratégia de manejo de irrigação: exemplos de cálculos. Sete Lagoas,
Embrapa. Circular Técnica 136. 25p.

Ashraf, M., Foolad, M. R. 2007. Roles of glycine betaine and proline in improving plant abiotic stress resistance. Environmental and Experimental Botany 59: 206-216.

Bates, L. S., Waldren, R. P., Teare, I. D. 1973. Rapid determination of free proline for waterstressstudies. Plant and Soil 39: 205-207.

Chiconato, D. A., Simoni, F. de, Galbiatti, J. A., Franco, C. F., Caramelo, A. D. 2013. Resposta da alface à aplicação de biofertilizante sob dois níveis de irrigação. Bioscience Journal 29: 392399.

Cvikrová, M., Gemperlová, L., Martincová, O., Vanková, R. 2013. Effect of drought and combined drought and heat stress on polyamine metabolism in proline over producing tobacco plants. Plant Physiology and Biochemistry 73: 7-15.

Diniz, A. A., Cavalcante, L. F, Rebequi, A. M., Nunes, J., Brehm, M. A. S. 2011. Esterco líquido bovino e ureia no crescimento e produção de biomassa do maracujazeiro amarelo. Revista Ciência Agronômica 42: 597-604.

Ferreira, D. F. 2007. Sisvar Versão 5.0. UFLA: Lavras, Brasil.

Filippou, P., Bouchagier, P., Skotti, E., Fotopoulos, V. 2014. Proline and reactive oxygen/nitrogen species metabolism is involved in the tolerant response of the invasive plant species Ailanthus altissima to drought and salinity. Environmental and Experimental Botany 97: 1-10.

Grieve, C. M., Grattan, S. R. 1983. Rapid assay for determination of water soluble quaternary ammonium compounds. Plant and Soil 70: 303307.

Guimarães, C. M., Stone, L. F., Oliveira, J. P. D., Rangel, P. H. N., Rodrigues, C. A. P. 2011 . Sistema radicular do arroz de terras altas sob deficiência hídrica. Pesquisa Agropecuária Tropical 41: 126134.

Gutierrez, R. S., Inocêncio, M. F., Novelino, J. O. 2011. Extração de silício em solos fertilizados com fosfato e silicato. Pesquisa Agropecuária Tropical 41: 1-7.

Mauad, M., Crusciol, C. A. C., Grassi Filho, H. 2011. Produção de massa seca e nutrição de cultivares de arroz de terras altas sob condições de déficit hídrico e adubação silicatada. Semina: Ciências Agrárias 32: 939-948.

Mauad, M., Crusciol, C. A. C., Grassi Filho, H., Machado, S. R. 2013. Deposição de sílica e teor de nitrogênio e silício em arroz. Semina: Ciências Agrárias 34: 1653-1662. 
Medeiros, D. C., Lima, B. A. B., Barbosa, M. R., Anjos, R. S. B., Borges, R. D., Cavalcante Neto, J. G., Marques, L. F. 2007. Produção de mudas de alface com biofertilizantes e substratos. Horticultura Brasileira 25: 433-436.

Menezes, B. R. S., Moreira, L. B., Lopes, H. M., Pereira, M. B. 2011. Caracterização morfoagronômica em arroz vermelho e arroz de sequeiro. Pesquisa Agropecuária Tropical 41: 490-499.

Monteiro, J. G., Cruz, F. J. R., Nardin, M. B., Santos, D. M. M. 2014. Crescimento e conteúdo de prolina em plântulas de guandu submetidas a estresse osmótico e à putrescina exógena. Pesquisa Agropecuária Brasileira 49: 18-25.

oro, A. L., Broetto, F., Moro, E. 2015. Relação hídrica e teor de clorofila em dois cultivares de arroz submetido à deficiência hidrica e adubação silicatada. Irriga 20: 570-586.

Neves, M. J., Terenzi, H. F., Leone, F. A., Jorge, J. A. 1994. Quantification of trehalose in biological samples with a conidial trehalose in biological samples with a conidial trehalase from the thermophilic fungus Hudicolagrisea var. thermoidea. World Journal of Microbiology \& Biotechnology 10: 17-19.

Nwugo, C. C., Huerta, A. J. 2008. Effects of silicon nutrition on cadmium uptake, growth and photosynthesis of rice plants exposed to low-level cadmium. Plant and Soil 31 1: 73-86.

Oliveira, L. A., Korndörfer, G. H., Pereira, A. C. 2007. Acumulação de silício em arroz em diferentes condições de $\mathrm{pH}$ da rizosfera. Revista Brasileira de Ciência do Solo 31: 685-690.

Pulz, A. L., Crusciol, C. A. C., Lemos, L. B., Soratto, R. P. 2008. Influência de silicato e calcário na nutrição, produtividade e qualidade da batata sob deficiência hídrica. Revista Brasileira de Ciência do Solo 32: 1651-1659.

Silva, F. L. B., Lacerda, C. F., Sousa, G. G., Neves, A. L. R., Silva, G. L., Sousa, C. H. C. 2011 . Interação entre salinidade e biofertilizante bovino na cultura do feijão-de-corda. Revista Brasileira de Engenharia Agrícola e Ambiental 15: 383-389.

Verbruggen, N., Hermans, C. 2008. Proline accumulation in plants: a review. Amino Acids 35: 753-759. 